\title{
Dynamic profile of SARS-CoV-2 infection among hospitalized patients in Kuwait: a descriptive study
}

Nada Madi $^{1 *}$ (D, Ebaa' Al-Awadhi ${ }^{2}$ and Fajer Al-Assaf ${ }^{3}$

\begin{abstract}
Background: The coronavirus induced disease 2019 (COVID-19) pandemic caused by the severe acute respiratory syndrome coronavirus 2 (SARS-CoV-2) in Wuhan (China) in December 2019 is currently spreading rapidly worldwide. This study aimed to analyze the dynamic profile of SARS-CoV-2 infection among hospitalized patients that would characterize the period of viral shedding and detection among patients.

Methods: Retrospectively, 103 confirmed SARS-CoV-2 patients hospitalized at Jaber hospital in Kuwait were included. Demographic and clinical characteristics of the patients were collected. Nasopharyngeal swabs were obtained at different time intervals and analyzed by Real-Time RT-PCR for SARS-CoV-2 infection.

Results: Of 103 hospitalized patients with SARS-CoV-2 infection, the median age was 41 years, and 64\% were male. The median period from admission to the positive SARS-CoV-2 RT-PCR test was 19 days (IQR, 13-22). The median period from admission to active negative SARS-CoV-2 RT-PCR test result was 22 days (IQR, 16-26). Older patients, patients with comorbidities, and patients with symptoms were more likely to have extended viral shedding.

Conclusion: For the first time, this descriptive study conducted in Kuwait on SARS-CoV-2 RT-PCR test results from 103 patients positive for SARS-provided solid proof and a good understanding of the dynamic profile of SARS-CoV-2 infection among patients in Kuwait. This information will further enrich the global knowledge on the emerging SARS-CoV-2.
\end{abstract}

Keywords: SARS-CoV-2, COVID-19, RT-PCR, Kuwait

\section{Background}

As of 14 March 2021, more than 119 million individuals worldwide were infected with severe acute respiratory syndrome coronavirus type 2 (SARS-CoV-2), the causative agent of coronavirus disease 2019 (COVID-19), and caused approximately 2.6 million deaths (https:// coronavirus.jhu.edu/map.html, accessed 14 March 2021). Indeed, SARS-CoV-2 constitutes a significant public health concern due to its high reproduction and

\footnotetext{
*Correspondence: nada.madi@ku.edu.kw

${ }^{1}$ Virology Unit, Department of Microbiology, Faculty of Medicine, Kuwait University, Kuwait City, Kuwait

Full list of author information is available at the end of the article
}

transmission rate, lack of immunity in the human population, lack of specific and active treatment and the lack of herd immunity from the recently authorized vaccines [1-3]. Recent reports suggested that even asymptomatic SARS-CoV-2 infected individuals could be the source of the virus $[4,5]$. Therefore, rapid and accurate diagnosis, tracing contacts, and isolation of suspected COVID19 cases are crucial in containing this pandemic [1]. The first confirmed case of SARS-CoV-2 in Kuwait was announced on 24 February 2020 by a group of travellers from Iran. There are 145,204 confirmed cases of SARS$\mathrm{CoV}-2$, 905 deaths with a $0.6 \%$ fatality rate, and $97.1 \%$ 
recovery rate (https://www.coronatracker.com/country/ kuwait/, accessed 10-Dec 2020).

SARS-CoV-2 infection is primarily diagnosed based on viral RNA detection by reverse transcriptase-polymerase chain reaction (RT-PCR) in samples from an individual's respiratory tract. So far, there is no descriptive study on the dynamic profile of SARS-CoV-2 in infected patients in Kuwait. Data on SARS-CoV-2 detection at different time points of an infection, including those without any symptoms, will help interpret the RT-PCR test results and to determine the period of viral shedding. Since the SARS-CoV-2 pandemic continues to date, this study's data will help inform Kuwait public health authorities on the right and convenient protocols for quarantine, contact tracing, and isolation. Therefore, this retrospective study aimed to study the dynamic profile of SARS-CoV-2 among infected patients hospitalized in Kuwait and determine the influence of demographic factors on it.

\section{Methods}

\section{Study population}

Retrospectively, 103 hospitalized patients (admission date from 12 March to 11 May 2020) confirmed SARS$\mathrm{CoV}-2$ infection in Jaber Hospital, Kuwait, were included in this study. Jaber Hospital is one of Kuwait's largest hospitals, assigned to hospitalize all individuals positive with SARS-CoV-2, whether symptomatic or asymptomatic, for centralized isolation following Kuwait policy. All enrolled patients were SARS-CoV-2 RT-PCR confirmed cases, and the patients with signs of COVID-19 had a confirmed diagnosis according to the diagnosis and treatment guidelines for SARS-CoV-2 from the Ministry of Health in Kuwait and the interim guidance from the Centre for Disease Control and Prevention [6]. Test dates and RT-PCR assay results were collected up to the final follow-up date before discharge (3 April to 24 May 2020).

\section{Data collection}

All data, including demographic and clinical information and RT-PCR results for SARS-CoV-2 viral nucleic acid detection, were collected from the electronic medical record system. The collected data were as follow 1 . Demographic characteristics, such as age, gender, nationality. 2. Clinical characteristics such as disease outcome (symptomatic or asymptomatic) and comorbidities. 3. SARS-CoV-2 RT-PCR test results. Nasopharyngeal swabs were collected from the patients to detect SARS-CoV-2 viral nucleic acid in sequential time-point during their hospitalization. Positive SARS-CoV-2 RT-PCR assay is defined as the period from the date of the first RT-PCR test to the last positive RT-PCR test result. Active negative SARS-CoV-2 RT-PCR assay is defined as the period from the first RT-PCR test to the first negative RT-PCR test result.

\section{Real-time reverse transcriptase PCR assays for SARS-CoV-2 RNA detection}

Nasopharyngeal swabs were collected from patients suspected of having a COVID-19 infection. According to the manufacturer's protocol, total RNA was extracted using the Roche MagNA Pure LC system (Roche Diagnostics, Indianapolis, IN, USA). The extracted RNA was used for one-step RT-PCR assays of COVID-19 RNA. Two genes, including ORF $1 \mathrm{a} / \mathrm{b}$ and $\mathrm{E}$ genes of SARSCoV-2, were detected using Cobas ${ }^{\circledR} 6800$ System and the Cobas ${ }^{\circledR}$ SARS-CoV-2 kit (Roche Diagnostic) according to the manufacturer's protocol. In this technique, the E gene detection was for screening, while ORF1b detection confirmed SARS-CoV-2. Also, LightMix ${ }^{\circledR}$ Modular SARS and Wuhan CoV E-gene and RdRP (RNA-dependent RNA polymerase) gene kits (TIB Molbiol, Berlin, Germany) with LightCycler Multiplex RNA Virus Master mix (Roche, Basel, Switzerland) were used according to the manufacturer's protocol. In this technique, the $\mathrm{E}$ gene detection was for screening, while RdRP detection confirmed SARS-CoV-2. Then, RT-PCR was performed on a LightCycler 480 II Real-Time PCR System (Roche Molecular Systems). A cycle threshold value (Ct-value) less than 37 was defined as a positive test result, and a Ct-value of 38 and more was described as a negative test result. Two techniques were used according to the availability of the kits.

\section{Statistical analysis}

All statistical analysis was performed using SPSS version 24.0 (IBM, NY, USA). Medians (interquartile range, IQR) and mean values were calculated for the contentious variables. Categorical variables and percentages were analyzed using the Mann-Whitney $U$ test. $\mathrm{P}$ values were reported as two-sided, with a significance level of 0.05 .

\section{Results}

\section{Demographic and clinical characteristics of the study population}

A total of 103 patients identified as SARS-CoV-2 positive by RT-PCR test were included in this study. The patients, including symptomatic and asymptomatic, were hospitalized in Jaber hospital once they tested positive for SARS-CoV-2 and followed up until discharged. The age of the patients ranged from 1 to 87 years, with a median age of 41 years (IQR, 28-56), compromising 66 (64\%) males and 37 (36\%) females (Table 1). Among the patients, 54 (52.4\%) were Kuwaiti, and 49 (47.6\%) were non-Kuwaiti. Asymptomatic individuals represented $49.5 \%$, which is almost half of the study population. 
Table 1 The demographic and clinical characteristics of the patients $(\mathrm{N}=103)$

\begin{tabular}{lc}
\hline Variable & All patients \\
\hline Age, median (IQR), y & $41(28-56)$ \\
$1-17$ & $8(7.8 \%)$ \\
$18-44$ & $50(48.5 \%)$ \\
$45-64$ & $35(34 \%)$ \\
$\geq 65$ & $10(9.7 \%)$ \\
Gender, $n$ (\%) & \\
Male & $66(64)$ \\
Female & $37(36)$ \\
Nationality, n (\%) & \\
Kuwaiti & $54(52.4)$ \\
Non-Kuwait & $49(47.6)$ \\
Asymptomatic, n (\%) & $51(49.45$ \\
Symptomatic, n (\%) & $52(50.5)$ \\
Fever & $39(75)$ \\
Cough & $29(55.7)$ \\
Sore throat & $11(21.2)$ \\
Headache & $7(13.5)$ \\
Shortness of breath & $4(7.7)$ \\
Myalgia & $4(7.7)$ \\
Runny nose & $2(3.8)$ \\
Diarrhoea & $1(1.9)$ \\
Vomiting & $1(1.9)$ \\
Without comorbidity, n (\%) & $66(64)$ \\
With comorbidity, $\mathrm{n}(\%)$ & $37(36)$ \\
Hypertension & $25(68)$ \\
Diabetes mellitus & $17(46)$ \\
Abstract dyslipidaemia & $6(16.2)$ \\
Ischemic heart disease & $6(16.2)$ \\
Bronchial asthma & $5(13.5)$ \\
Hypothyroidism & $3(8.1)$ \\
Chronic kidney disease & $1(2.7)$ \\
Breast cancer & $1(2.7)$ \\
\hline IR &
\end{tabular}

IQR interquartile range

According to SARS-CoV-2 [6] guidelines, all symptomatic patients had mild to moderate SARS-CoV-2 infection; however, no patient was transferred to ICU. The most predominant symptoms among patients were fever (75\%), followed by cough $(55.7 \%)$ (Table 1$)$. The sore throat was detected in $21.2 \%$ of the patients, headache in $13.5 \%$, shortness of breath in $7.7 \%$, and myalgia in $7.7 \%$. Runny nose was found in $3.8 \%$; however, diarrhoea and vomiting were detected in only $0.9 \%$ of the patients. Patients with comorbidities represented $36 \%$ of the study population, while the rest (64\%) were without comorbidities (Table 1). Among patients with comorbidities, 68\% had hypertension, $46 \%$ had diabetes mellitus, $16.2 \%$ had abstract dyslipidaemia and ischemic heart disease, 13.5\% had bronchial asthma, and $8.1 \%$ had hypothyroidism, while only $2.7 \%$ of the patients had chronic kidney disease and breast cancer (Table 1).

\section{The dynamic profile of SARS-CoV-2 infection}

The total number of SARS-RTPCR assay tests performed from 103 patients infected with SARS-CoV-2 was 529 tests, with an average of five tests per patient. The median period from the date of admission to the first SARSCoV-2 RT-PCR was seven days (IQR, 0-10). The median period from admission to the last SARS-CoV-2 RT-PCR test was 23 days (IQR, 8-28, range, 6-53) (Table 2). The median period from admission to positive SARS-CoV-2 RT-PCR test was 19 days (IQR, 13-22, range, 0-37), while the median period from admission to active negative SARS-CoV-2 RT-PCR test result was 22 days (IQR, 16-26; range, 3-53) (Table 2). The details on the dynamic profile of SARS-CoV-2 infection is shown in Fig. 1A. In the first three weeks after admission, the majority of results of RT-PCR for SARS-CoV-2 were positive, while negative results started to be detected from week two. In week four, the number of positive and negative RTPCR results were the peak. Nevertheless, from week six onward, both positive and negative RT-PCR results declined.

\section{Influence of age and gender on the dynamic profile of SARS-CoV-2}

The impact of age and gender on the dynamic profile of the SARS-CoV-2 RT-PCR assay was also studied.

Table 2 SARS-CoV-2 RT-PCR assay results

\begin{tabular}{|c|c|c|c|c|c|}
\hline \multirow[t]{2}{*}{ Variable } & \multicolumn{5}{|l|}{ Median (IQR), day } \\
\hline & Total tests $(n=529)$ & $\begin{array}{l}\text { Asymptomatic } \\
\text { patients }\end{array}$ & $\begin{array}{l}\text { Symptomatic } \\
\text { patients }\end{array}$ & $\begin{array}{l}\text { Patients with } \\
\text { comorbidity }\end{array}$ & $\begin{array}{l}\text { Patients } \\
\text { without } \\
\text { comorbidity }\end{array}$ \\
\hline First SARS-CoV-2 RT-PCR & $7(0-10)$ & $7(0-10)$ & $8(1-11)$ & $6(0-10)$ & $7(1-10)$ \\
\hline Last SARS - CoV-2 RT PCR & $23(18-28)$ & $24(18-28)$ & $22(17-27)$ & $25(20-29)$ & $23(17-26)$ \\
\hline Positive SARS-CoV-2 RT-PCR & $19(13-22)$ & $24(18-28)$ & $22(17-27)$ & $25(20-29)$ & $23(17-26)$ \\
\hline Active negative SARS-CoV-2 RT-PCR & $22(16-26)$ & $19(13-22)$ & $19(13-22)$ & $23(17-28)$ & $22(16-25)$ \\
\hline
\end{tabular}




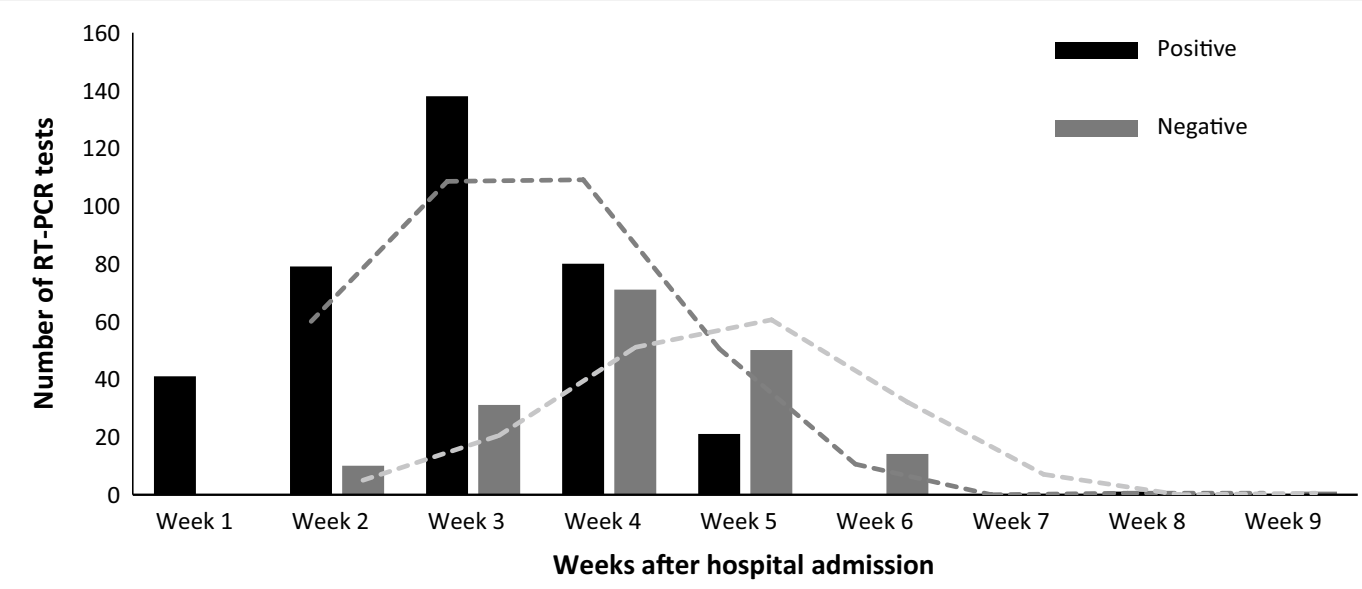

Fig. 1 The dynamic profile of SARS-CoV-2 detected by RT-PCR from 103 patients ( $n=539$ tests). The number of positive and negative results of SARS-CoV-2 RT-PCR tests was summed weeks after the admission

For a more comprehensive analysis, the age group was divided into $<65$ and $\geq 65$ years. Figure $2 \mathrm{~A}$ shows no significant difference in the median period of positive SARS-CoV-2 PCR test result between patients aged $<65$ and patients aged $\geq 65$ years $(19$ days, IQR, $17-26$ and 19 days, IQR, 15-27, $P=0.3$, respectively). However, the median period of negative SARS-CoV-2 RT-PCR test results in patients aged $<65$ years was longer than in patients aged $\geq 65$ years, but without significant difference (22 days, IQR, 17-26 and 19 days, IQR, 127, $P=0.12$, respectively). As shown in Fig. 2B, male patients had a comparable median period of positive and negative SARS-CoV-2 RT-PCR test results to female patients (19 days, IQR, $13-23$ vs 18 days, IQR, $13-22, \mathrm{P}=0.56$ ) and (22 days, IQR, 17-26, vs 21 days, IQR, 16-25, $P=0.43)$, respectively.

\section{SARS-CoV-2 shedding}

Based on the period of active negative SARS-CoV-2 RT-PCR test results, the patients were divided into two groups; patients with extended shedding of the virus $(\geq 24$ days) and patients with non-extended shedding of the virus ( $\leq 24$ days). Only $40(38.8 \%)$ patients had extended viral shedding, while $63(61.2 \%)$ had nonextended viral shedding $(P=0.001)$. As shown in Table 3, patients with extended viral shedding tended to be older. Patients with extended viral shedding were more likely to have comorbidities than patients with non-extended viral shedding, but without a noticeable significant difference $(P=0.2)$. Moreover, patients without comorbidities tended to have non-extended viral shedding, still without a considerable difference $(P=0.2)$. However, the percentage of symptomatic patients who had extended viral shedding was, to some extent, more than the percentage of symptomatic patients who had non-extended viral shedding. Also, asymptomatic patients tended to have non-extended viral shedding, but again without a noticeable difference $(P=0.7)$.

\section{Discussion}

This is the first descriptive study conducted in Kuwait on SARS-CoV-2 RT-PCR test results from 103 patients positive for SARS-CoV-2. This study provided solid proof and a good understanding of the dynamic profile of SARSCoV-2 infection among patients in Kuwait during the continuous SARS-CoV-2 pandemic. The first cases of SARS-CoV-2 were recorded in February 2020 from travellers arriving from Iran. At the early phase of the pandemic, all patients detected positive for SARS-CoV-2 by RT-PCR were hospitalized regardless of the infection's outcome (symptomatic or asymptomatic). SARS-CoV-2 infection was monitored during hospitalization by RTPCR on sequential nasopharyngeal swabs collected from the patients. This study showed that males with a median age of 41 years were the favourable group for the infection. The asymptomatic patients were almost equal in number to the symptomatic patients. It is worth mentioning that the asymptomatic patients in this study never developed any symptoms throughout the hospitalization. Studying asymptomatic individuals' epidemiological significance is essentially better to understand COVID-19 pathogenesis [7, 8]. SARS-CoV-2 generally causes flu-like symptoms, such as fever (93\%) [9], non-productive cough (50\%) [10], dyspnoea (34.5\%), myalgia (27.7\%), headache (7.2\%), whereas diarrhoea and vomiting may precede these symptoms $(6.1 \%)[9,10]$. Rhinorrhoea was noted in only $4.0 \%$ [11] and sore throat in 5.1\% [12]. However, the symptoms may become severe and lead to ICU 

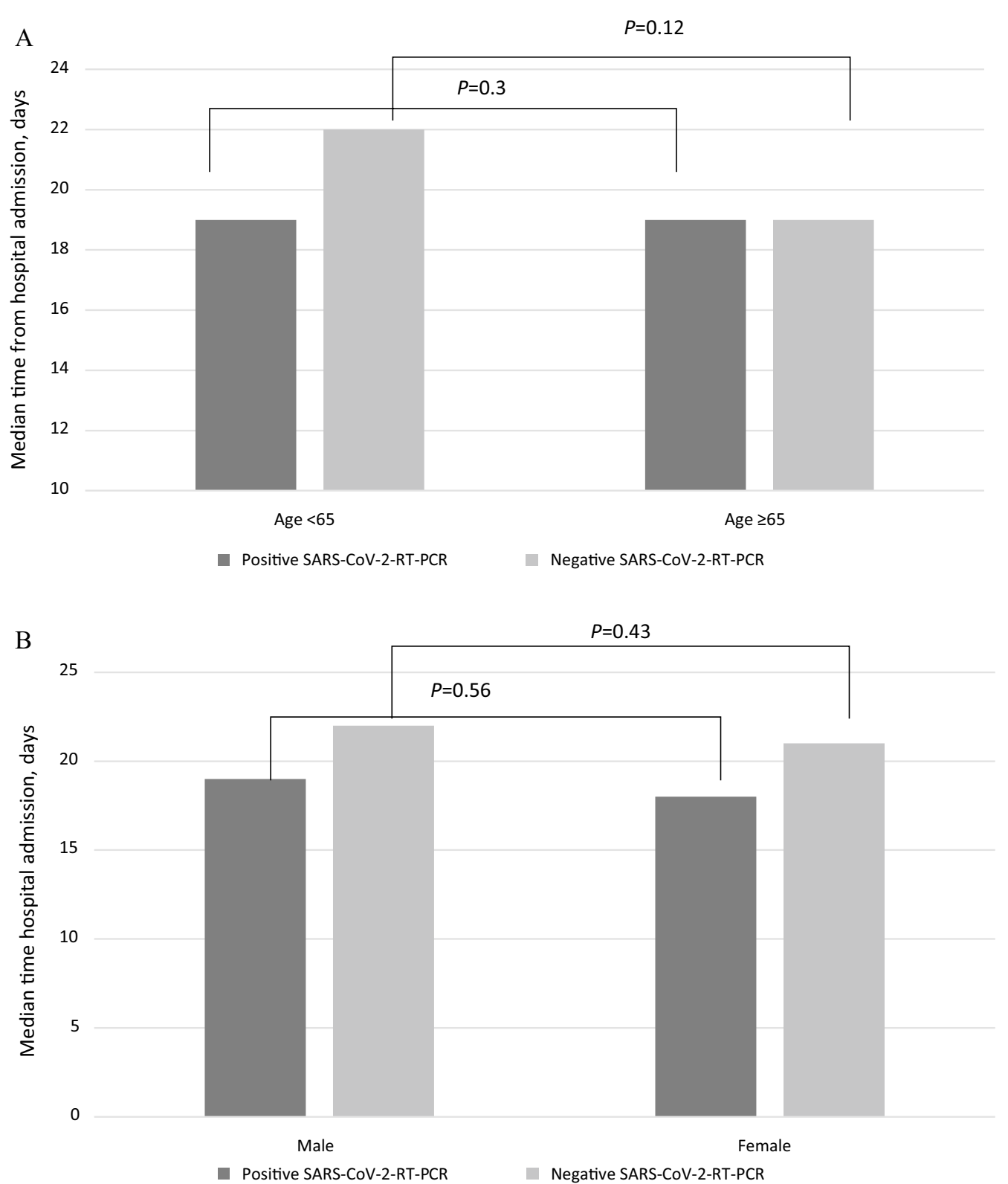

Fig. 2 Influence of age and gender on the dynamic profile of SARS-CoV-2. A The median period of positive SARS-CoV-2 RT-PCR and active negative SARS-CoV-2 RT-PCR grouped by age. B The median period of positive SARS-CoV-2 RT-PCR and active negative SARS-CoV-2 RT-PCR grouped by gender

admission, while others die from the complications. All the patients had mild to moderate; $75 \%$ developed fever, while $55.7 \%$ developed cough, $21.2 \%$ had sore throat. Headache was found in $13.5 \%$; however, other symptoms were developed in a lower percentage of the patients, such as shortness of breath (7.7\%), myalgia (7.7\%), runny nose $(3.8 \%)$, vomiting and diarrhoea (1.9\%). The most prevalent underlying disease among patients positive for SARS-CoV-2 in our study was hypertension (68\%), followed by diabetes mellitus (46\%). Comorbidities may contribute to the severe and progressive COVID-19[13]. A study by Chen ZM et al. (2020) has demonstrated that cardiovascular disease and hypertension were the most common underlying diseases, followed by diabetes mellitus, among adult patients [9].

This study's main goal was to analyze the dynamic profile of SARS-CoV-2 infection among hospitalized patients that would characterize the period of viral shedding and 
Table 3 Viral shedding in SARS-CoV-2 positive patients

\begin{tabular}{|c|c|c|c|c|}
\hline Variable & $\begin{array}{l}\text { All patients } \\
N=103\end{array}$ & $\begin{array}{l}\text { Extended shedding } \\
(\geq 24 \text { days }) \\
n=40\end{array}$ & $\begin{array}{l}\text { Non-extended } \\
\text { shedding } \leq \mathbf{2 4} \text { days) } \\
n=63\end{array}$ & P-value \\
\hline Age, median (IQR), years & $41(28-56)$ & $45(29-56)$ & $40(27-54)$ & 0.3 \\
\hline \multicolumn{5}{|l|}{ Comorbidity, n (\%) } \\
\hline Yes & $37(36 \%)$ & $17(42.5 \%)$ & $20(31.7 \%)$ & 0.2 \\
\hline No & $66(64 \%)$ & $23(57.5 \%)$ & $43(68.3 \%)$ & 0.2 \\
\hline \multicolumn{5}{|l|}{ Symptoms } \\
\hline Yes & $52(50.1 \%)$ & $21(52.5 \%)$ & $31(49.2 \%)$ & 0.7 \\
\hline No & $51(49.5 \%)$ & $19(47.5 \%)$ & $32(50.8 \%)$ & 0.7 \\
\hline
\end{tabular}

$I Q R$ interquartile range

detection among patients. Our results showed that the median period between hospital admission and positive SARS-CoV-2 RT-PCR test result was 19 days (IQR, 13-22). However, there were no significant differences in the period of viral detection between patients with symptoms and patients without symptoms, suggesting the possibility of transmission by asymptomatic patients. Also, the significant differences in viral detection period between patients with comorbidities and patients without comorbidities were lacking. The median period for active negative (first negative) RT-PCR test results was 22 days (IQR, 16-26), without noticeable differences between different patients' categories. We showed that most RT-PCR tests were positive at week three with a gradual decrease trend after that (Fig. 1). On the other hand, the negative results of RT-PCR tests start to increase from week two after admission, peaked at week four and then began to decrease until the end of follow-up (6 weeks) (Fig. 1). In parallel to our results, a study reported a median period of viral shedding of 20 days (range, 8-37 d) in191 patients with COVID-19 [14]. However, a study in Singapore in patients infected with SARS-CoV-2 showed that the period of viral shedding was extended to 24 days after symptom onset [15]. The studies on the duration of virus shedding in symptomatic and asymptomatic patients were varied $[16,17]$. In parallel to our results, Zhuo et al. have shown that the duration of viral shedding remained similar in the symptomatic and asymptomatic patients (7 days) [18].

However, Yongchen et al. have shown that the median period of virus detection in asymptomatic patients was longer (18 days) compared with patients with severe disease (14 days) and patients with mild symptoms (10 days) [19]. Other studies showed that the period of SARS$\mathrm{CoV}-2$ detection in hospitalized asymptomatic patients ranged from 7 to 23 days $[17,20]$.

We studied the influence of demographic factors on the dynamic profile of SARS-CoV-2 infection. Our results showed no significant differences in the median duration of positive or negative SARS-CoV-2 results between patients aged $<65$ and $\geq 65$ or between males and females. In contrast to our study, a study has shown that infected older patients ( $\geq 65$ years old) had a significantly extended period of positive SARS-CoV-2 RT-PCR test results than patients $<65$ years [21]. Another study has shown that the median SARS-CoV-2 viral positivity duration was significantly shorter in younger patients [22].

The correlation between clinical characteristics and the duration of viral shedding in patients positive for SARS-CoV-2 was also explored. Our results showed that patients with extended viral shedding ( $\geq 24$ days) are likely to be older and have comorbidities. Also, patients with symptoms had a slightly more extended period of viral shedding than patients without symptoms. Studies on the association between the duration of viral shedding and older age showed inconsistent results, where some studies showed positive associations [21, 23, 24], while others showed no association [14].

Our study has several limitations. At the beginning of the pandemic, the accuracy of SARS-CoV-2 varied; however, significant improvements in the detection protocol and sampling experience were achieved until the current time. Second, information on the viral load, which is lacking in this study, will reflect the virus's infectivity during the disease course. Third, this study only investigated the profile of SARS-CoV2 infection in nasopharyngeal swabs, while other samples such as different respiratory samples, blood and stools samples should be included. Finally, this study's lack of virus culture data reduced its credibility in viral infectivity during the disease course. RT-PCR is considered the gold standard technique for detecting SARS-CoV-2 due to its high sensitivity and specificity rates and the ability to quantify the virus. However, the technique has some limitations-first, the possibility of false-positive results may range from 2 to $37 \%$. Second, many diagnostic platforms that target spike (S) 
gene showed false-negative results due to the emergence of new variants of SARS-CoV-2 such as B.1.1.7 lineage. Another diagnostic tool that has a crucial role in diagnosing COVID-19 is chest computed tomography (CT). $\mathrm{CT}$ has a role in detecting pulmonary changes among COVID-19, monitoring disease progression, and guiding therapy [25].

\section{Conclusion}

In summary, this is the first study in Kuwait that demonstrated the dynamic profile of SARS-CoV-2 infection by analyzing the test results of the SARS-CoV-2 RT-PCR assay. The median duration of viral detection of 19 days after onset of symptoms and hospital admission, and older age and comorbidities may have more extended viral shedding and more complications. This information will further enrich the global knowledge on the emerging SARS-CoV-2. We recommend a more extensive scale study involving many patients to understand the dynamic profile of SARS-CoV-2 infection better.

\section{Abbreviations}

COVID-19: Coronavirus induced disease 2019; SARS-CoV-2: Severe acute respiratory syndrome coronavirus 2; RT-PCR: Reverse transcriptase-polymerase chain reaction.

\section{Acknowledgements}

Special thanks to the outstanding work of all medical staff in all hospitals in Kuwait. Great appreciation goes to all laboratory technicians at Jaber hospital to devote time and effort during the SARS-CoV-2 pandemic in Kuwait.

\section{Authors' contributions}

NM designed the study. EA and FA provided RT-PCR and clinical data. NM analyzed the data. NM drafted and revised the manuscript. All authors read and approved the final manuscript.

\section{Funding}

No funding resources were declared for this study.

\section{Availability of data and materials}

The datasets used and/or analyzed during the current study are available from the corresponding author on reasonable request.

\section{Declarations}

\section{Ethics approval and consent to participate}

The Ethics Committee of the Ministry of Health, Kuwait, approved this study (project no. 1577/2020). Since this is a retrospective study, informed consent from the participants was not obtained and considered unnecessary, according to the Ethics Committee of the Ministry of Health of Kuwait. The ethical approval authorized the process of access the raw data without any specific administrative permission. The data used in this study were anonymized before its use.

\section{Consent for publication}

Not applicable.

\section{Competing interests}

The authors declare that they have no competing financial interests or personal relationships that could have affected the work reported in this paper.

\section{Author details}

${ }^{1}$ Virology Unit, Department of Microbiology, Faculty of Medicine, Kuwait University, Kuwait City, Kuwait. ${ }^{2}$ Jaber Al-Ahmad Al-Sabah Hospital, Ministry of Health, Kuwait City, Kuwait. ${ }^{3}$ Al-Farwaniya Hospital, Ministry of Health, Kuwait City, Kuwait.

Received: 10 January 2021 Accepted: 30 July 2021

Published online: 05 August 2021

\section{References}

1. Walsh KA, Jordan K, Clyne B, Rohde D, Drummond L, Byrne P, et al. SARSCoV-2 detection, viral load and infectivity over the course of an infection. J Infect. 2020. https://doi.org/10.1016/j.jinf.2020.06.067.

2. Rabi FA, Al Zoubi MS, Al-Nasser AD, Kasasbeh GA, Salameh DM. Sars-cov-2 and coronavirus disease 2019: what we know so far. Pathogens. 2020. https://doi.org/10.3390/pathogens9030231.

3. Murchu EO, Byrne P, Walsh KA, Carty PG, Connolly M, De Gascun C, et al. Immune response following infection with SARS-CoV-2 and other coronaviruses: a rapid review. Rev Med Virol. 2020. https://doi.org/10.1002/ rmv.2162.

4. Zou L, Ruan F, Huang M, Liang L, Huang H, Hong Z, et al. SARS-CoV-2 viral load in upper respiratory specimens of infected patients. N Engl J Med. 2020. https://doi.org/10.1056/NEJMc2001737.

5. Rothe C, Schunk M, Sothmann P, Bretzel G, Froeschl G, Wallrauch C, et al. Transmission of 2019-nCoV infection from an asymptomatic contact in Germany. N Engl J Med. 2020. https://doi.org/10.1056/NEJMc2001468.

6. National Center for Immunization and Respiratory Diseases, Division of Viral Diseases. Interim infection prevention and control recommendations for patients with suspected or confirmed coronavirus disease 2019 (COVID-19) in Healthcare Settings. Cdc. 2020.

7. Gandhi M, Yokoe DS, Havlir DV. Asymptomatic transmission, the Achilles' heel of current strategies to control COVID-19. N Engl J Med. 2020. https://doi.org/10.4324/9781003141402-4

8. Arons MM, Hatfield KM, Reddy SC, Kimball A, James A, Jacobs JR, et al. Presymptomatic SARS-CoV-2 infections and transmission in a skilled nursing facility. N Engl J Med. 2020. https://doi.org/10.1056/NEJMoa2008457.

9. Chen ZM, Fu JF, Shu Q, Chen YH, Hua CZ, Li FB, et al. Diagnosis and treatment recommendations for pediatric respiratory infection caused by the 2019 novel coronavirus. World J Pediatr. 2019. https://doi.org/10.1007/ s12519-020-00345-5.

10. Ortiz-Prado E, Simbaña-Rivera K, Gómez- Barreno L, Rubio-Neira M, Guaman LP, Kyriakidis NC, et al. Clinical, molecular, and epidemiological characterization of the SARS-CoV-2 virus and the Coronavirus Disease 2019 (COVID-19), a comprehensive literature review. Diagn Microbiol Infect Dis. 2020. https://doi.org/10.1016/j.diagmicrobio.2020.115094.

11. Chen N, Zhou M, Dong X, Qu J, Gong F, Han Y, et al. Epidemiological and clinical characteristics of 99 cases of 2019 novel coronavirus pneumonia in Wuhan, China: a descriptive study. Lancet. 2019. https://doi.org/10. 1016/S0140-6736(20)30211-7.

12. Huang C, Wang Y, Li X, Ren L, Zhao J, Hu Y, et al. Clinical features of patients infected with 2019 novel coronavirus in Wuhan, China. Lancet. 2019. https://doi.org/10.1016/S0140-6736(20)30183-5.

13. Wang D, Hu B, Hu C, Zhu F, Liu X, Zhang J, et al. Clinical characteristics of 138 hospitalized patients with 2019 novel coronavirus-infected pneumonia in Wuhan, China. JAMA J Am Med Assoc. 2020. https://doi.org/10. 1001/jama.2020.1585

14. Zhou F, Yu T, Du R, Fan G, Liu Y, Liu Z, et al. Clinical course and risk factors for mortality of adult inpatients with COVID-19 in Wuhan, China: a retrospective cohort study. Lancet. 2020. https://doi.org/10.1016/S01406736(20)30566-3.

15. Young BE, Ong SWX, Kalimuddin S, Low JG, Tan SY, Loh J, et al. Epidemiologic features and clinical course of patients infected with SARS-CoV-2 in Singapore. JAMA J Am Med Assoc. 2020. https://doi.org/10.1001/jama. 2020.3204.

16. Hu Z, Song C, Xu C, Jin G, Chen Y, Xu X, et al. Clinical characteristics of 24 asymptomatic infections with COVID-19 screened among close contacts in Nanjing, China. Sci China Life Sci. 2020. https://doi.org/10.1007/ s11427-020-1661-4 
17. Le TQM, Takemura T, Moi ML, Nabeshima T, Nguyen LKH, Hoang VMP, et al. Severe acute respiratory syndrome coronavirus 2 shedding by travelers, Vietnam, 2020. Emerg Infect Dis. 2020. https://doi.org/10.3201/eid2607. 200591.

18. Zhou R, Li F, Chen F, Liu H, Zheng J, Lei C, et al. Viral dynamics in asymptomatic patients with COVID-19. Int J Infect Dis. 2020;96:288-90.

19. Yongchen Z, Shen H, Wang X, Shi X, Li Y, Yan J, et al. Different longitudinal patterns of nucleic acid and serology testing results based on disease severity of COVID-19 patients. Emerg Microbes Infect. 2020. https://doi. org/10.1080/22221751.2020.1756699.

20. Lo IL, Lio CF, Cheong HH, Lei Cl, Cheong TH, Zhong X, et al. Evaluation of sars-cov-2 rna shedding in clinical specimens and clinical characteristics of 10 patients with COVID-19 in Macau. Int J Biol Sci. 2020. https://doi. org/10.7150/ijbs.45357.

21. Tang Xiao A, Xin Tong Y, Gao C, Zhu L, Jie Zhang Y, Zhang S. Dynamic profile of RT-PCR findings from 301 COVID-19 patients in Wuhan, China: a descriptive study. SSRN Electron J. 2020. https://doi.org/10.2139/ssrn. 3548769.

22. Yan W-H, Lin A, He Z-B, Zhang S, Zhang J-G, Zhang X, et al. Clinical infectious diseases early risk factors for the duration of severe acute respiratory syndrome coronavirus 2 viral positivity in patients with coronavirus disease 2019. Clin Infect Dis. 2020;71:2061-6. https://doi.org/10.1093/cid/ ciaa490.

23. Lescure FX, Bouadma L, Nguyen D, Parisey M, Wicky PH, Behillil S, et al. Clinical and virological data of the first cases of COVID-19 in Europe: a case series. Lancet Infect Dis. 2020. https://doi.org/10.1016/S14733099(20)30200-0.

24. An J, Liao X, Xiao T, Qian S, Yuan J, Ye H, et al. Clinical characteristics of the recovered COVID-19 patients with re-detectable positive RNA test. Ann Transl Med. 2020. https://doi.org/10.1101/2020.03.26.20044222.

25. Razek A, Fouda N, Fahmy D, Tanatawy MS, Bilal M, Zaki M, Abdel-Aziz M, Sobh D. Computed tomography of the chest in patients with COVID-19: what do radiologists want to know? Polish J Radiol. 2021;86:122-35.

\section{Publisher's Note}

Springer Nature remains neutral with regard to jurisdictional claims in published maps and institutional affiliations.
Ready to submit your research? Choose BMC and benefit from:

- fast, convenient online submission

- thorough peer review by experienced researchers in your field

- rapid publication on acceptance

- support for research data, including large and complex data types

- gold Open Access which fosters wider collaboration and increased citations

- maximum visibility for your research: over 100M website views per year

At BMC, research is always in progress.

Learn more biomedcentral.com/submissions 